\title{
Rate of physical appearance changes on yellowness in salak during preservation in room storage
}

\author{
Widia Pangestika ${ }^{1}$, Ahmad Ni’matullah Al-Baarri ${ }^{2,3 *}$, Anang Mohamad Legowo ${ }^{3}$, Mulyana Hadipernata ${ }^{4}$, Wisnu \\ Broto $^{4}$, Laili Izzati ${ }^{3}$
}

\begin{abstract}
Background: Discoloration was one indicator of food damage including in fruits, since the change may be used as a quality measurement. Salak became one of the commodities that often experience the browning reaction that may change the color. Since the yellow was close to the consumer preference along the preservation in salak, this color should be notified and may be represented as polyphenol change.

Objectives: The focus of this study was to determine the pattern of inhibition of browning reactions in salak using HIO.

Methods: This research determined the color level of yellow using digital color meter of salak that was stored in room temperature in aseptic treatment for 12 days.

Result: Discoloration appeared in salak and it was clearly determined the change since a week of storage. The rate of discoloration was able to be detected highly after one week of storage.

Conclusion: The discoloration of yellow color and the rate of salak could be detected specifically based on the day of storage. This research may open the information for the consumer to predict the storage time of salak based on the appearance of yellow color.
\end{abstract}

Keyword: physical appearance; yellow color; salak; browning; storage

\section{INTRODUCTION}

Fruit is one of the commodities that is easily damaged. One of the damage to the fruit is browning. Enzymatic browning of the fruit is divided into two namely enzymatic and non-enzymatic browning ${ }^{1}$. The enzymatic browning reaction in the fruit can be caused by the oxidative reaction of polyphenol oxidase (PPO) enzyme which reacts with oxygen which will produce a brownish color in the fruit ${ }^{2}$. Many fruits of tropical or subtropical origin can run to browning ${ }^{3}$ like salak.

Salak cultivar Pondoh is one of infamous native tropical fruits in Sleman, Yogyakarta. This fruit is favored not only by local consumers but also overseas consumers for its taste and crunchy texture. Besides, it is also rich in nutrient content including dietary fiber and antioxidant ${ }^{4}$. According to data from National Statistic Agency, it was recorded that export of salak in 2015 and 2016 had increased from 758 to 790 ton followed by increasing demand along with its growing popularity. Some of the destination countries for the export are Singapore, Middle East country, Netherlands, Hongkong, and China ${ }^{5}$. However, salak is perishable commodities and have short-aging. In general, salak can be stored at \pm 7 days at room temperature and it will be prolonged at low temperature ${ }^{6}$.
The process of color change that often occurs is the color change to brown as a result of the process of stripping, cutting or exposed to collisions, this process is called the enzymatic browning reaction ${ }^{7}$. Browning is caused by the oxidation of phenolic compounds in the fruit which is catalyzed by the enzyme PPO when the fruit is damaged by cell structure and then produces quinone compounds, these compounds which cause the color to brown ${ }^{8}$. Browning in fruits can reduce product quality and reduce consumer interest ${ }^{9}$. Efforts to inhibit the browning reaction in this fruit have been done using enzyme inhibiting chemical compounds such as ascorbic and citric acid, but until now documentation of chemical compound inhibiting enzyme from organic groups, is still very limited in number ${ }^{10}$. This methods leaves a negative impact on the taste due to the treatment. Therefore, it is necessary to have enzyme inhibiting compounds that do not have negative impact on taste. One alternative is hypoiodous acid (HIO). HIO is a weak acid that has been widely used for antibacterial and antifungal properties ${ }^{11}$.

$\mathrm{HIO}$ is a compound formed form the reaction of two substrates, namely hydrogen peroxide $\left(\mathrm{H}_{2} \mathrm{O}_{2}\right)$ and KI which are catalyzed by the peroxidase enzyme ${ }^{11}$. Peroxidase enzyme is an enzyme that can catalyze the transfer of $\mathrm{H}$ atoms, $\mathrm{O}$ atoms, or electrons from one substrate to another ${ }^{12}$. The enzyme can be obtained

\footnotetext{
${ }^{1}$ Department of Nutrition Science, Universitas Diponegoro. J1. Prof. Sudarto SH, Tembalang, Semarang, Jawa Tengah 50275, Indonesia

${ }^{2}$ Central Laboratory for Research and Service, Universitas Diponegoro. J1. Prof. Sudarto SH, Tembalang, Semarang, Jawa Tengah 50275, Indonesia

${ }^{3}$ Food Technology Department, Faculty of Animal and Agricultural Sciences, Universitas Diponegoro. J1. Prof. Sudarto SH, Tembalang, Semarang, Jawa Tengah 50275, Indonesia

${ }^{4}$ Indonesian Agency for Agricultural Research and Development, Indonesian Ministry of Agriculture. Jl. Tentara Pelajar No. 12, Bogor, Jawa Barat 16122, Indonesia

* Corresponding author: e-mail: albari@ live.undip.ac.id
} 
from the results of isolation and purification in several plants ${ }^{13}$, one of which is radish. The focus of this study was to determine the pattern of inhibition of browning reactions in salak using HIO.

\section{MATERIALS AND METHODS}

Chemical materials and enzyme. $\mathrm{H}_{2} \mathrm{O}_{2}$ and $\mathrm{KI}$ were purchased from Roche (Germany) and $2 \mathrm{mM}$ of those substrates was applied. The salak was obtained from local farm form Sleman, Yogyakarta with 5-month harvest age. Horseradish for the source of peroxidase enzyme from modern market in Tembalang, Semarang, Indonesia. Aquadest and phosphate buffer were obtained from Center of Research and ServicesDiponegoro University, Indonesia.

Salak sortation. Preparation of salak used as sample referred to ${ }^{14}$ with modification. Salak were harvested from the orchard located in Sleman, Yogyakarta with relatively same harvest age and transported using container box to prevent possible physical injury. The salak fruits were manually picked from the bunch and carefully cleaned with brush to remove the dirt on its skin. Unhealthy and bruised fruits were discarded and fruits weighing 60-80 g were selected. After sorting, fruits were placed in 2 different container boxes according to the treatment, sprayed with HIO and with distilled water. All processes were carried out aseptically.

HIO solution preparation. The method from previous research from ${ }^{15}$. HIO solution was made from $\mathrm{H}_{2} \mathrm{O}_{2}(2 \mathrm{mM})$, KI (2 mM), and peroxidase enzyme in ratio 4.5:4.5:1. All of the solutions were mixed in beaker glass and stirred. The mixture was allowed to react for 6 minutes. After 6 minutes, the HIO solution was ready to use.

Peroxidase enzyme preparation. Preparation of peroxidase enzyme from Daikon radish was following the method from ${ }^{16}$ to obtain the crude extract of peroxidase enzyme from natural sources. Radish were washed and cut into small pieces. The cuts were weighed and blended with phosphate buffer $(0.01 \mathrm{M}$, $\mathrm{pH} 7$ ) in ratio $1: 4$. The blended radish was filtered with filter cloth to obtain the juice. The juice then centrifuged for 10 minutes with the speed of $10000 \mathrm{rpm}$ using Scilogex DM0412 centrifuge. The supernatant and sediment were separated by filter cloth and the supernatant was used as peroxidase enzyme that produces peroxidase enzyme of $4,5 \mathrm{U} / \mathrm{ml}$.

Application of HIO on salak. This procedure was adopted and modified from previous study by ${ }^{17}$. The container boxes used to store the salak fruit were sprayed and cleaned with alcohol before use to avoid contamination. Each fruit was aseptically sprayed with and without HIO solution as much as $1 \mathrm{ml}$. All of the fruits were then put into the container boxes according to the treatment group and covered with plastic wrap, stored in room temperature for 12 days. These fruits were analyzed every 3 days.

Analysis for $b^{*}$ value. Testing of the $b^{*}$ value referred to the method of ${ }^{18}$ with modification. The pointed end of the salak was cut to size of $1 \mathrm{~cm} \mathrm{x} 1 \mathrm{~cm}$ $\mathrm{x} 1 \mathrm{~cm}$ and measured in 3 different areas of each replicate. Data analysis was carried out using Microsoft Excel then the results were presented in scatter chats with tread line and also explained descriptively.

\section{RESULTS}

\section{Change in $b^{*}$ Value}

The results of changes in $\mathrm{b}$ value of salak fruit at room temperature, can be seen in Figure 1. The data was in form of spraying treatment of salak with HIO and aquades which stored at room temperature.

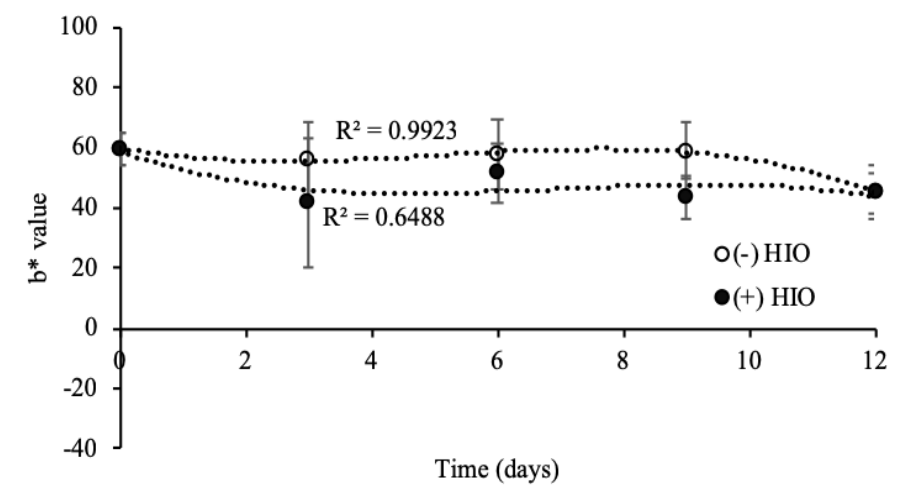

Figure 1. b* Value of Salak Stored during Room Temperature

\section{The Michaelis-Menten Curve}

Figure 2 means that quadratic rate each of which produces a formula $\mathrm{y}=-1.5971 \mathrm{x}^{2}+20.604 \mathrm{x}$ and $\mathrm{y}=$ $1.4073 \mathrm{x}^{2}+17.409 \mathrm{x}$, respectively for curves without addition and with addition of HIO.

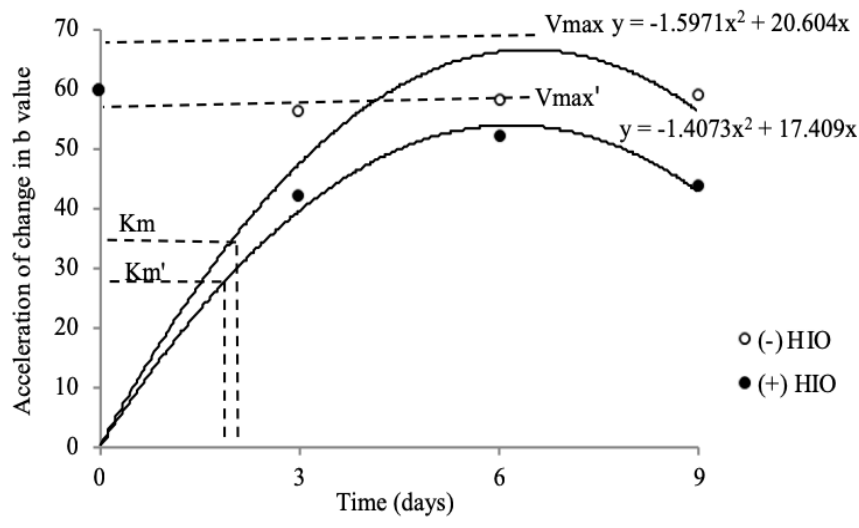

Figure 2. Michaelis- Menten's Curve PPO Enzyme for Salak 


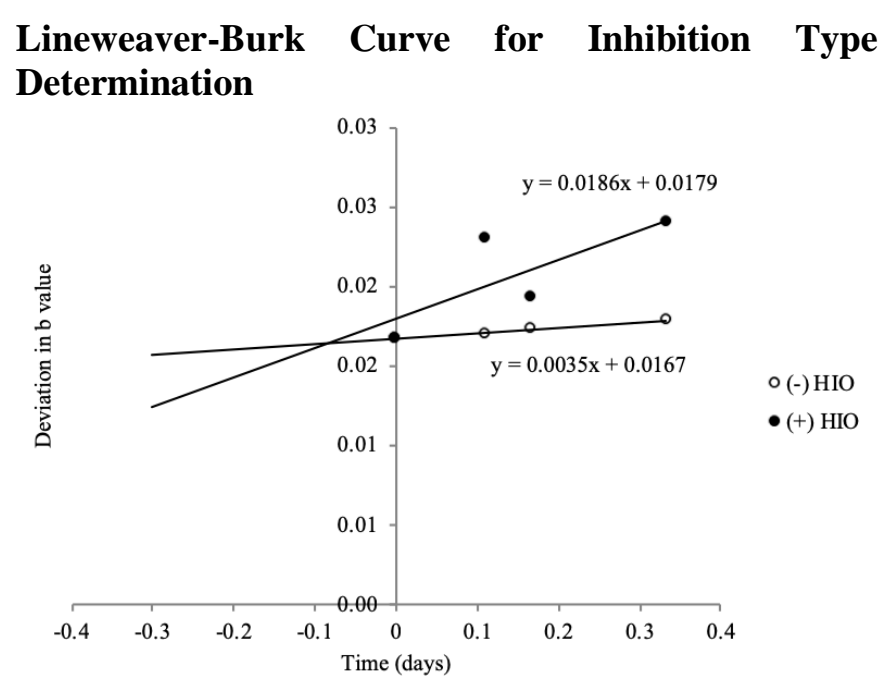

Figure 3. Lineweaver-Burk Plot curve

\section{Enzyme Kinetics}

$\mathrm{V}_{\max }$ and $\mathrm{K}_{\mathrm{m}}$ values are generated using graphical analysis as shown in Figure 2, while $\mathrm{K}_{\mathrm{i}}$ values are calculated after the known $\mathrm{V}_{\max }$ and $\mathrm{K}_{\mathrm{m}}$ values.

Table 1. PPO Enzyme Kinetic Value Data with HIO Inhibitors

\begin{tabular}{ll}
\hline & HIO Inhibitors \\
\hline $\mathrm{K}_{\mathrm{m}}$ & 29 \\
$\mathrm{~V}_{\max }$ & 58 \\
$\mathrm{~K}_{\mathrm{i}}$ & 13.11 \\
Type of inhibition & Uncompetitive \\
\hline
\end{tabular}

\section{DISCUSSION}

\section{Change in $b^{*}$ Value}

Figure 1 showed that $b^{*}$ value of salak with HIO treatment has decreased during storage. In general, the graph obtained from non HIO treatment results are lower than HIO treatment. Decrease in $b^{*}$ value is considered fast and can only last for 12 days then salak cannot be analyzed further because the discoloration process begins. This is same with previous research which states that the color change on the initial day was no difference, but the color of fruit decreased during storage for less than 14 days, indicating a yellow-brown effect ${ }^{18}$. Brwoning is caused by the oxidation of phenolic compounds in the fruit which is catalyzed by the enzyme PPO when fruit is damaged by the cell structure and then produces quinone compounds, these compounds which cause the color to brown ${ }^{8}$. The $\mathrm{b}^{*}$ values of salak which treated with $\mathrm{HIO}$ has an $\mathrm{R}^{2}$ value of 0.6488 which indicates that the fruit tends to be far from yellowness color. Although the $b^{*}$ value shows change that tend to be positive, the $b^{*}$ value cannot be used as a direct indicator that affects browning reactions, this is because the $b^{*}$ value has a weak relationship with PPO enzyme activity ${ }^{15}$.

\section{The Michaelis-Menten Curve}

The Michaelis-Menten Curve is an indicator that can be used to describe changes in enzyme kinetics and to provide inhibitory characteristics for enzyme activity ${ }^{19}$. $\mathrm{K}_{\mathrm{m}}$ and $\mathrm{V}_{\max }$ values are two main parameters in the enzyme kinetics study, each of which represents the Michaelis-Menten constanta which can be used to estimate the number of substrates and acceleration reaction ${ }^{20}$. The acceleration reaction will continue to increase until it reaches the limit point indicating that the activity of this enzyme has reached its maximum limit, this point is called $\mathrm{V}_{\max }{ }^{21}$.

The curve of change in $b^{*}$ value in Figure 2 means that the higher the absorbance value, the more brown the salak fruit according to the quadratic rate each of which produces a formula $\mathrm{y}=-1.5971 \mathrm{x}^{2}+$ $20.604 x$ and $y=-1.4073 x^{2}+17.409 x$, respectively for curves without addition and with addition of HIO. The peak that can be reached on each curve is called $\mathrm{V}_{\max }$, so $\mathrm{V}_{\max }$ is the maximumrate that can be achieved in a reaction without the addition of $\mathrm{HIO}$ and $\mathrm{V}_{\max }$ is the maximum rate that can be obtained in the reaction by adding HIO. Based on the range of $\mathrm{V}_{\max }$ values obtained, $\mathrm{V}_{\max }$ of the PPO enzyme with the addition and without addition of HIO occurred on the sixth days that indicating the maximum ability of the PPO enzyme to carry out chemical reaction activities which is characterized by the acceleration of the browning reaction which become slow that ultimately the enzyme cannot function ${ }^{22}$. This Michaelis-Menten curve forms the basis for forming the Lineweaver-Burk curve to determine the value of $\mathrm{K}_{\mathrm{m}}$ and $\mathrm{V}_{\max }{ }^{23}$ and also to find out the type of inhibition.

\section{Lineweaver-Burk Curve for Inhibition Type Determination}

The browning reaction inhibition mechanism analyzed from the Lineweaver-Burk plot curve (Figure 3 ) shows that the type of inhibition of HIO enzymes in salak is uncompetitive inhibitor. ${ }^{24}$ explains that uncompetitive inhibitors have no intersection points on the $\mathrm{x}$ or $\mathrm{y}$ axis. The mechanism of inhibition differs depending on the inhibitor used. HIO can bind the allosteric side of PPO enzyme that arise when the enzyme binds to the enzyme in the enzyme-substrate complex and can inhibit its activity ${ }^{25}$.

\section{Enzyme Kinetics}

Table 1 shows the kinetic values of $\mathrm{HIO}$ inhibitors with $K_{m}, V_{\text {max }}$ and $K_{i}$ values are 29; 58 and 13.11 The Vmax value shows the level of enzyme saturation by the substrate while Km shows the catalyst efficiency of the enzyme which is seen as the concentration of a particular substrate when the catalytic velocity of the enzyme reaches half $\mathrm{V}_{\max }{ }^{21}$. A low inhibition constant value indicates the strength of the inhibitor inhibits the enzyme activity of each unit ${ }^{25}$. 
The constant value obtained is equal to the value of the citric acid constant which is equal to $13^{26}$.

\section{CONCLUSION}

The conclusion obtained from this study is HIO is able to maintain salak from enzymatic browning reaction, Inhibition ability increases with increasing concentrations of HIO. The mechanism of HIO inhibition is type of uncompetitive inhibition.

\section{ACKNOWLEDGMENTS}

The author would like to thank the Ministry of Research, Technology and Higher Education for funding all of this research through an international publication research scheme.

ABBREVIATIONS
$\begin{array}{ll}\mathrm{PPO} & \text { : polyphenol oxidase } \\ \mathrm{HIO} & \text { : hypoiodous acid } \\ \mathrm{H}_{2} \mathrm{O}_{2} & \text { : hydrogen peroxide } \\ \mathrm{KI} & : \text { potassium iodide } \\ \mathrm{K}_{\mathrm{m}} & : \text { michaelis konstant } \\ \mathrm{V}_{\max } & : \text { the maximal rate of reaction with inhibitors } \\ \mathrm{V}_{\max } & : \text { the maximal rate of reaction without inhibitors } \\ \mathrm{K}_{\mathrm{i}} & \text { : quantitative measure of potential inhibitors }\end{array}$

\section{REFERENCES}

1. Persic, M., Mikulic-Petkovsek, M., Slatnar, A., Veberic, R. Chemical composition of apple fruit, juice and pomace and the correlation between phenolic content, enzymatic activity and browning. LWT - Food Science and Technology. 2017;82:2331.

2. Plazas, M., López-Gresa, M. P., Vilanova, S., Torres, C., Hurtado, M., Gramazio, P., Prohens, J. Diversity and relationships in key traits for functional and apparent quality in a collection of eggplant: fruit phenolics content, antioxidant activity, polyphenol oxidase activity, and browning. Journal of Agricultural and Food Chemistry. 2013;61(37):8871-79.

3. Chidtragool, S., Ketsa, S., Bowen, J., Ferguson, I. B., Van Doorn, W. G. Chilling injury in mango fruit peel: Cultivar differences are related to the activity of phenylalanine ammonia lyase. Postharvest Biology and Technology. 2011;62(1):59-63.

4. Saleh, M. S. M., M. J. Siddiqui, A. Mediani, N. H. Ismail, Q. U. Ahmed, S. Z. M. So'ad, S. SaidiBesbes. Salacca zalacca: A short review of the palm botany pharmacological uses and phytochemistry. Asia Pacific Journal of Tropical Medicine. 2018;11(12):645-52.
5. Arfa, N. N., B. S. Daryono, Reflinur. Comparison of detergent and CTAB method for isolation of DNA from Salak (Salacca zalacca (Gaert.) Voss. 'Pondoh'). Biology, Medicine, and Natural Product Chemistry. 2018;7(1):15-20.

6. Santosa, O. C. Chatib, K. Fahmy, F. Artika. Investigation the effect of chitosan coating and temperature storage to extend the shelf life zalacca (Salacca zalacca). International Journal on Advanced Science, Engineering and Information Technology. 2016;6(3):394-402.

7. Singh, B., Suri, K., Shevkani, K., Kaur, A., Kaur, A., Singh, N. Enzymatic browning of fruit and vegetables: a review. Enzymes in Food Technology. 2018;63-78.

8. Gomes, M. H., T. Vieira, J. F. Fundo, D. P. F. Almeida. Polyphenoloxidase activity and browning in fresh-cut 'Rocha' pear as affected by $\mathrm{pH}$, phenolic substrates, and antibrowning additives. Postharvest Biology and Technology. 2014;91:328.

9. Nadafzadeh, M., S. A. Mehdizadeh, M. Soltanikazemi. Development of computer vision system to predict peroxidase and polyphenol oxidase enzymes to evaluate the process of banana peel browning using genetic programming modeling. Scientia Horticulturae. 2018;231:201-9.

10. Ioannou, I. , M. Ghoul. Prevention of enzymatic browning in fruit and vegetables. European Scientific Journal. 2013;9(30):310-41.

11. Bafort, F., O. Parisi, J.P. Perraudin , M.H. Jijakli. Mode of action of lactoperoxidase as related to its antimicrobial activity: a review. Enzyme Research. 2014;1-13.

12. Lopes, L. C., M. T. M. Barreto, K. M. Gonçalves, H. M. Alvarez, M. F. Heredia, R. O. M. A. de Souza, Y. Cordeiro, C. Dariva, A. T. Fricks. Stability and structural changes of horseradish peroxidase: microwave versus conventional heating treatment. Enzyme and Microbial Technology. 2015;69:10-8.

13. Puri, M., Sharma, D., Barrow, C. J. Enzymeassisted extraction of bioactives from plants. Trends in Biotechnology. 2012;30(1):37-44.

14. Tehranifar, A., M. Zarei., Z. Nemati., B. Esfandiyari, M. R. Vazifeshenas. Investigation of physico-chemical properties and antioxidant activity of twenty Iranian pomegranate (Punica granatum L.) cultivars. Scientia Horticulturae. 2010;126(2):180-5.

15. Al-Baarri, A N, A M Legowo, A C D. Wratsongko, A D Puspitoasih, L Izzati , EAuliana, Michael , W Pangestika , M Hadipernata , W Broto. Effect of hypoiodous acid (HIO) treatment on color and $\mathrm{pH}$ changes in snake fruit (Salacca edulis Reinw.) during room temperature storage. 
IOP Conf. Series: Earth and Environmental Science. 2019;292.

16. Lavery, C. B., M. C. MacInnis., M .J. MacDonald., J. B. Williams., C . A. Spencer., A. A. Burke., J. G. I. David, G. B. D'Cunha. Purification of peroxidase from horseradish (Armoracia rusticana) roots. Journal Agricultural and Food Chemistry. 2010;58(15):8471-76.

17. Kyi, A., N. Nyo, K. Myint, T.T Soe. Postharvest handling system of agricultural produce in Myanmar. Acta Horticulture. 2013;298:253-8.

18. Techavuthiporn, C., P. Boonyaritthongchai, S. Supabvanich. Physicochemical changes of pineapple fruit treated with short-term anoxia during ambient storage. Food Chemistry. 2017;228:383-93.

19. Li, B., B. Li, Y. Shen. A much better replacement of the michaelis-menten equation and its application. International Journal of Biomathematics. 2019;12(1).

20. Guerra, N. P. Enzyme kinetics experiment with the multienzyme complex viscozyme 1 and two substrates for the accurate determination of michaelian parameters. Journal of Chemical Education. 2017;94(6):795-9.
21. So, K., Kitazumi, Y., Shirai, O., Kurita, K., Nishihara, H., Higuchi, Y., Kano, K. Kinetic analysis of inactivation and enzyme reaction of oxygen-tolerant [NiFe]-hydrogenase at direct electron-transfer bioanode. Bulletin of the Chemical Society of Japan. 2014;87(11):1177-85.

22. Bajwa, V. S., Shukla, M. R., Sherif, S. M., Murch, S. J., Saxena, P. K. Identification and characterization of serotonin as an anti-browning compound of apple and pear. Postharvest Biology and Technology. 2015;110:183-9.

23. Choi, B., Rempala, G. A., Kim, J. K. Beyond the Michaelis-Menten equation: accurate and efficient estimation of enzyme kinetic parameters. Scientific Reports. 2017;7(1).

24. Mardiah, E. Mekanisme inhibisi enzim polifenol oksidase pada sari buah markisa dengan sistein dan asam askorbat. J. Ris. Kim. 2011;4(2):32-7.

25. Purich, D.L. Enzyme kinetics catalysis control: a reference of theory and best-practice methods. Elseiver Inc. 2010. United Kingdom.

26. Gouzi, H., T. Coradin, E. N. Delicado, M. U. Unal, A. Benmansour. Inhibition kinetics of Agaricus bisporus (J.E. Lange) imbach polyphenol oxidase. The Open Enzyme Inhibition Journal. 2010;3:1-7. 